\title{
COVID-19 and intimate partner violence in Zimbabwe: Towards being church in situations of gender-based violence from a public pastoral care perspective
}

\begin{tabular}{|c|c|}
\hline \multicolumn{2}{|c|}{$\begin{array}{l}\text { Authors: } \\
{\text { Vhumani Magezi }{ }^{1} \text { (D) }}^{\text {Peter Manzanga }}{ }^{1} \text { (D) }\end{array}$} \\
\hline \multicolumn{2}{|c|}{$\begin{array}{l}\text { Affiliations: } \\
{ }^{1} \text { Unit for Reformational } \\
\text { Theology and the } \\
\text { Development of the SA } \\
\text { Society, Faculty of Theology, } \\
\text { North-West University, } \\
\text { Potchefstroom, South Africa }\end{array}$} \\
\hline \multicolumn{2}{|c|}{$\begin{array}{l}\text { Corresponding author: } \\
\text { Vhumani Magezi, } \\
\text { vhumani@hotmail.com }\end{array}$} \\
\hline \multicolumn{2}{|c|}{$\begin{array}{l}\text { Dates: } \\
\text { Received: } 02 \text { July } 2020 \\
\text { Accepted: } 12 \text { Oct. } 2020 \\
\text { Published: } 15 \text { Dec. } 2020\end{array}$} \\
\hline \multicolumn{2}{|c|}{$\begin{array}{l}\text { How to cite this article: } \\
\text { Magezi, V. \& Manzanga, P., } \\
\text { 2020, 'COVID-19 and intimate } \\
\text { partner violence in } \\
\text { Zimbabwe: Towards being } \\
\text { church in situations of } \\
\text { gender-based violence from } \\
\text { a public pastoral care } \\
\text { perspective', In die Skriflig } \\
\text { 54(1), a2658. https://doi. } \\
\text { org/10.4102/ids.v54i1.2658 }\end{array}$} \\
\hline \multicolumn{2}{|c|}{$\begin{array}{l}\text { Copyright: } \\
\text { (C) 2020. The Authors } \\
\text { Licensee: AOSIS. This } \\
\text { is licensed under the } \\
\text { Creative Commons } \\
\text { Attribution License. }\end{array}$} \\
\hline \multicolumn{2}{|l|}{ Read online: } \\
\hline 口ifin & $\begin{array}{l}\text { Scan this QR } \\
\text { code with your } \\
\text { smart phone or } \\
\text { mobile device } \\
\text { to read online. }\end{array}$ \\
\hline
\end{tabular}

The COVID-19 global pandemic negatively transformed social, religious and economic life globally. Countries implemented national lockdowns among other measures to mitigate against the spread of the pandemic. Zimbabwe is among the countries that pronounced a national lockdown. The national lockdown accelerated the already existing gender-based violence (GBV) scourge. GBV manifested in various forms especially by people that are intimate partners to the victims. The new environment caused by COVID-19 has proven that intimate partner violence (IPV) remains one of the key causes of GBV. Written from a public pastoral care perspective, this article examines the COVID-19 pandemic national lockdown in Zimbabwe and how it provided a convenient environment for the acceleration of IPV. The church is caught unaware, and its role is barely visible as a key microcosm of society. in a view of this, the following three questions emerge: first, what does it mean to be church in a real GBV situation caused by COVID-19?; second, what public pastoral care roles could the church frame to mitigate GBV by IPV in the COVID-19 situation?; and third, how could such public pastoral care responsive roles impact the broader community by not being exclusively church based? The article seeks to address these questions by, first, providing the introduction and background to COVID-19 and GBV in Zimbabwe. Second, it discusses IPV as a key form of GBV and its implications on COVID-19 national lockdown environment. Third, it analyses what it means to be church in an environment of COVID-19. Fourth, it proposes some public pastoral responsive care roles by the church with a transformative impact on the broader community and provides a conclusion.

Keywords: COVID-19 and church; intimate partner violence (IVP); gender-based violence (GBV); GBV and church in Zimbabwe; public pastoral care; pastoral care and community.

\section{Introduction and background}

The COVID-19 global pandemic is unparalleled and has affected the day-to-day unfolding of human life in many countries. Gender-based violence (GBV) during COVID-19 has been called a pandemic within a pandemic (Mutongwiza 2020; United Nations Fund for Population Activities [UNFPA] 2020). The national lockdown is among many mitigating measures implemented by different countries to reduce the spread of the pandemic. Among other nations, the government of Zimbabwe also imposed a national lockdown. Instead of the national lockdown rendering an environment where women and their partners could spend peaceful time together, it accelerated intimate partner violence (IPV) in Zimbabwe. Prior to the COVID-19 pandemic, Zimbabwe has been already a fertile ground for GBV.

According to the United Nations Zimbabwe (2020 also cited in Zimbabwe Demographic Health Survey [ZDHS] 2010-2011; 2015):

\footnotetext{
... 1 in 3 women aged 15 to 49 have experienced physical violence, while about 1 in 5 women has
} experienced sexual violence since the age of 15 , usually by their intimate partners. (n.p.)

Most of the GBV cases in Zimbabwe and in other countries are perpetrated by somebody known and close to the victim (Kruttschnitt et al. 2018; United Nations Women [UNW] 2016; World Health Organisation [WHO] 2013). This logically follows that GBV is a threat in environments where women should feel safe (Heise, Ellsberg \& Gottmoeller 2002:S6-S7; Jewkes 2002:1423; Mutepfa 2009:77; Nhlapo 2017; Shamu et al. 2013). As such, the national lockdown in Zimbabwe subjected women to IPV as a form of GBV. The national lockdown 
facilitated a situation whereby women and their already abusive partners were 'locked' together for a longer time under one roof. This allowed pre-existing negative social norms, and gender inequalities, coupled with restricted movement of abusive partners led to an increase in GBV (United Nations Development Programme [UNDP] 2020). Pre-existing abusers and potential abusers spent longer time with victims resulting in strained relationships. Consequently, António Guterres, the UN Secretary General strongly urged:

\begin{abstract}
... all governments to make the prevention and redress of violence against women a key part of their national response plans for COVID-19 ... We know lockdowns and quarantines are essential to suppressing COVID-19. But they can trap women with abusive partners. Over the past weeks as economic and social pressures and fear have grown, we have seen a horrifying global surge in domestic violence. (United Nations Zimbabwe 2020)
\end{abstract}

According to the Office for the Coordination of Humanitarian Affairs (OCHA 2020), Musasa Project recorded the following data on abuses perpetrated from the beginning of Zimbabwe national lockdown due to COVID-19:

- The national GBV Hotline (Musasa) has recorded a total of 2276 GBV calls from the beginning of the lockdown on 30 March until 03 June.

- An overall increase of over $75 \%$ compared to the prelockdown trends.

- About $94 \%$ of the cases are women.

- The most dominant forms are physical violence (38\% of total cases) and psychological violence (38\%), followed by economic violence (19\%) and sexual violence (5\%).

- About $90 \%$ of cases are IPV cases (OCHA 2020; ZIMFACT 2020).

There are various drivers that contribute as accessories to GBV by partners in Zimbabwe during COVID-19. First, the country's already frail economy is a good source of financial insecurity for families. Financial insecurity and not being able to provide for the family could, for most men, be an insult to their male ego, which could sometimes lead to abusive behaviour. Second, alcohol abuse within the home environment or alcohol withdrawal symptoms could lead to violence. Third, the inability during national lockdown to access socio-psychological support from both secular and religious counsellors could increase the rate of GBV. Fourth, some partners had already lived in abusive relationships before COVID-19. A prolonged stay together in a national lockdown situation doubled or tripled the chances of GBV (Mutongwiza 2020; ZIMFACT 2020). Fifth, loss of income and stress could lead to violent behaviour by partners. Some women who were financially independent means that they must rely in their husbands for the support of the family. The result of such dependence could trigger the abuse of women. In view of the current GBV surge in Zimbabwe, IPV plays a major role in the injustices and human rights abuses for women and girls (WHO 2012). As documented above, IPV accounts for $90 \%$ of the cases and this indicates a need to understand IPV better through this article. Hence, the following section seeks to conceptualise IPV as a key source of GBV during COVID-19 national lockdown in Zimbabwe.

\section{Understanding intimate partner violence}

IVP is a widespread and high-ranking form of violence against women that has caught scholarly attention for decades (Julia, Watts, Hargreaves, et al. 2011:1794; Kruttschnitt et al. 2018:477; WHO 2013). Synonymous terms for IPV often used, are 'wife beating', 'battering' or 'domestic violence'. IVP is defined as a pattern of abusive and imposed behaviour which include physical, sexual and psychological attacks, as well as economic coercion that adults or adolescents use against their intimate partners (Julia et al. 2011:1794). Rio and Valle (2017:1171) advance that 'controlling behaviour alone often is the first expression of mistreatment'. Such behaviour includes a range of sexually, psychologically and physically coercive acts used against adult or adolescent women by a current intimate partner without her consent (EIGE 2017:35-40; Heise \& Ellsberg 1999; Population International Services [PSI] 2015:3; Watts \& Zimmerman 2002).

From the preceding definition of IPV, it reveals that this form of GBV is complicated, as it includes a range of abuses which could be difficult to fully comprehend. The term IPV also emphasises that this form of GBV originates not from a total stranger, but from someone close and known to the victim. In this type of violence, women suffer extreme emotional depression, suppression and beating, and ultimately are murdered. Citing the UN High Commissioner for Refugees (UNHCR), Watts and Zimmerman (2002:1233) revealed that an estimated $40 \%-70 \%$ of homicides are perpetrated by intimate partners, and that one in every three women has been beaten, forced into sex or has been abused in their life.

The WHO conducted a population-based survey to establish the prevalence of IPV. Data was gathered on IPV from more than 24000 women. The women consulted, also represented different cultures, geographical locations and urban or rural settings. The results below summarise the findings by the WHO (2010) and reveal that IPV is a deep-seated form of GBV:

- $13 \%-61 \%$ reported ever having experienced physical violence from a partner.

- $4 \%-49 \%$ reported having experienced severe physical violence by a partner.

- $6 \%-59 \%$ reported sexual violence by a partner at some point in their lives.

- $20 \%$ - $75 \%$ reported experiencing one emotionally abusive act or more from a partner in their lifetime.

According to the United Nations Women (UNW 2018), IPV remains a global challenge. An estimated 35\% of women experience physical or sexual violence from an intimate partner. However, national studies show that $70 \%$ of women have suffered and/or experienced physical and/or sexual violence from an intimate partner. Furthermore, the results 
reveal that nearly half of the women who were victims of homicide in 2012 were murdered by their intimate partners (UNW 2018).

Intimate partner violence has its dynamics. Among them is the belief that a man has the right to control the behaviour of his wife and whom she socialises with. Such restrictions are not equally expected of a man from his wife. In addition, a woman who challenges a man's right by asking for money or reminding him about the needs of children may be punished. Under the current national lockdown situation, such reminders by wives to partners are more inclined to basic commodities, which partners fail to deliver resulting in GBVrelated tensions. In countries like Malawi, South Africa, Mozambique, Nigeria and Zimbabwe, IPV is predominantly understood as chastisement (Heise \& Ellsberg 1999:6). In some situations where the husband beats his wife, the police will not intervene, because GBV is considered a domestic affair and legal instruments may not treat wife abuse as an offence (Ayodapo 2013:3). Counts, Brown and Campbell (1992:315) maintain that 'such justification for male dominance and abuse of women emanate from gender norms, which are social norms proper roles and responsibilities of men and women'.

In situations of extreme IPV, people often ask: 'Why doesn't she leave him?' Women who experience IPV are caught up in a quandary to stay with or leave the abusive partner. Some can leave and return several times before they finally leave (Landenburger 1998:131-135). Unfortunately, leaving does not necessarily guarantee a woman's safety. It is possible that violence will continue or even get worse after the woman leaves a partner. Leaving puts a woman at risk of getting murdered (Heise \& Ellsberg 1999:7). The WHO (2012; Weed n.d:9-10) list some reasons why women experiencing IPV may delay leaving:

- Lack of alternative means of economic support

- Concern for children

- Isolation from family, friends, places of worship, and community resources

- Facing reality

- Lack of support from family and friends

- Stigma or fear of losing custody of children associated with divorce

- Love and the hope that the partner will change

- Religious and cultural beliefs, teachings, and traditions offered to females by spiritual leaders, congregational laity, educators, family members, and other segments of society instruct women and girls to assume a subservient role to males. Often these precepts are said to be ordained by God

- The perpetrator's threats to kill, kidnap, or physically harm the victim's children, parents, siblings, pets, and the victim herself, or threats to kill himself. It should be noted that all threats made by perpetrators must be taken seriously. By far the most dangerous times for a victimised woman is when she begins disclosing the abuse and when she attempts to leave her abusive partner.
On the other hand, women would rather continue to endure IPV for the following reasons pointed out by Ayodapo (2013:2-3): First, a woman may remain with an abusive partner, because she is financially or economically dependent on him. She may be unskilled or not employed and simply a housewife with children. So, the fear of raising children alone, shatter any hope for the future without depending on her partner. Second, she may remain with an abusive partner, because culture condones the behaviour of the abusive partner. Societal norms influence her decisions in that leaving might put her under the spotlight as a stubborn and uncultured woman in society. Third, a woman suffering IPV would rather maintain her identity by being called someone's wife or lover, particularly in Africa. Women may jostle to get the title 'Mrs' at the cost of their personal happiness. This emanates from the notion that society deems that a woman's identity is attached to men.

Staying at home during the COVID-19 national lockdown in Zimbabwe, is proving to be unsafe for some women and girls as IPV surges. Even families that may not have experienced violence before, could begin to experience violence. This is caused by the sudden change in social life through disconnection of daily support systems and community resources. Victims of IPV face great risk of getting injured or even death in cases of extreme violence against them (Substance Abuse and Mental Health Service Administration [SAMHSA] 2020:1). The SAMHSA (2020) further maintain that in this situation:

... the support systems that many at-risk parents rely on, such as extended family, childcare and schools, religious groups and other community organisations, are no longer available in many areas due to the stay-at-home orders. (p. 3)

Implicit in the preceding quotation is the importance of community for humanity in daily interaction as a way of dealing with the problems in society. The national lockdown has exposed the pertinent need for community as crucial to alleviate a social problem such as IPV. Although this pandemic is unprecedented, the public pastoral care roles of the church need to be understood as sustaining the community aspect during COVID-19 national lockdown. Given the above conception of IPV and the interruption of support systems for victims of IPV, an understanding of the church within the exponential surge of IPV in COVID-19 national lockdown is pertinent.

\section{Conception of the church within practical ministry of gender-based violence amidst the COVID-19 pandemic}

Clowney (1998:140) argues that defining the meaning of 'church' helps us to understand its nature and how it is supposed to publicly function as a 'fundamental reality of the Christian faith'. The conception of church should not only be confined to denominational affiliation. A broad uniting factor should define what church is as God intends. 
This allows for an understanding of the church towards better practical outward care practices in particular situations such as IPV during COVID-19 national lockdown. Therefore, the greater meaning and mission of the church should be understood by, '... describing the identity and purpose of the church by looking at God's identity and plan or mission with creation and humankind' (Hendriks 2007:999).

The church is defined as a community of all genuine believers who, by grace through faith, confess Jesus Christ as their Lord and Saviour. The church embodies believers of all time covering the Old and New Testament eras. Jesus builds his church by calling people to himself (Mt 16:18). The church is also the dwelling of God among his people as fulfilled by Jesus Christ through his incarnation (Jn 1:14; 2:19, 20) and later, after his ascension, he dwells among his people through his Holy Spirit (Jn 16:12-14; Clowney 1998:140). The presence and public ministry of God among his people continues through the agency of his Holy Spirit.

\section{The church as incarnational (operative) component of society}

The church should be incarnational in its approach to ministry. Being incarnational means to be present, public, prophetic and interacting with issues affecting society. This would also mean that the church views and understands itself as an instrument of Christ in the world (Dingemans 1996:93). Andria and Saayman (2003:503) describe the church in Africa as defective for failing to make transformation in its societies. Hence, they argue for new ecclesiology in Africa that makes a visible impact in its communities on different aspects of life. According to Andria and Saayman (2003:503), the new ecclesiology should be involved in public life. In other words, 'the church is church only when it is there for others' (Lawrence 2013:113).

The COVID-19 pandemic has created a new lifestyle for humanity, and the church should be alert to frame solutions to a public issue such as IPV arising from the restrictions caused by the pandemic. Brodd (2006:124) states that the 'understanding of being Church might be hidden or openly operative in ecclesial life'. It is the open operative aspect of ecclesiology we are concerned with in public pastoral theology rather than a 'hidden' church. An operative ecclesiology could be what Andria and Saayman (2003:503) are proposing when they use the term new ecclesiology. Practically, the church forms a context in which the gospel:

\footnotetext{
... can be mediated and realised. As an embodiment of koinoniathe fellowship of believers, the congregation forms the context in which pastoral encounter can take place. Encounter means the communication process that takes place between God and humanity within a real situation where they discover meaning through faith and guided by scripture ... pastoral encounter is humane and contextual. (Louw 1998:70)
}

The concept of operative ecclesiology was introduced by a French Dominican scholar called Yves Congar (1904-1995) (Brodd 2006:124). Magezi and Magezi (2018:7) state that 'operative ecclesiology entails engaging pressing public issues within concrete situations of people rather than abstractions. This means the Bible and dogmas are brought to bear on communal life systems'.

If the goal of operative ecclesiology is to bear an impact on public issues affecting people, it logically entails that practical theology and ecclesiology as theological disciplines are closely related (Magezi \& Magezi 2018:7). For operative ecclesiology to be truly functional, the church should socially engage public issues such as IPV during and after COVID-19. In other words, what the church cherishes as its dogma must be expressed in a manner that addresses contextual issues affecting society. This implies that the church must be vigilant in identifying issues affecting humanity. Hendriks (2007:1002) argues that the church must 'discern how to participate in the missional praxis of the triune God and as such, how to become what God wants his people to be: his image, his body'. The church can participate better in the missional praxis of God if it continues to align itself with the character of God who formed it. Such character of God is possible if the community of believers reflects the image of God by relating to the Creator and care for humanity in needy and deplorable situations such as IPV.

Hendriks (2007) further adds that:

God revealed Himself as the God who heard the voices of slaves, who took notice of the suffering of people with no social standing. He called them, they obeyed his call and they became his people. (p. 1007)

The church also should strive at engaging its congregational members towards being transformative in society (Hendriks 2007:1000). The goal of the church in becoming involved with society is to transform communities of faith and broader community through its theological teachings, which should 'address society's issues and problems in a holistic way' (Hendriks 2007:1000) with relevance to the context in which they exist.

The relevance of operative ecclesiology must be the goal of the pragmatic task of the church by seeking to provide guidance and transforming assistance (Magezi \& Magezi 2018:7; Osmer 2008:11) regarding public issues such as IPV during COVID-19. This means that operative ecclesiology within practical ministry, justifies the need for operative public pastoral care by church.

\section{An operational conception of public theology}

The above section set out to understand what the church is and how it should function within practical ministry. The section argued for operational ecclesiology in the context of practical ministry. It argued that the church must not be defective but rather operational by holistically dealing with public contextual issues that affect people such as IPV as a form of GBV. The relevance of this understanding means that 
the church must be public in its approach to ministry. If the church must be public in its approach, it logically entails that public theology is indispensable. Hence, this section seeks to accomplish three things: to establish an understanding of what public theology is; set out the importance and value of public theology in public issues; and finally, link public theology with practical theology as an umbrella for practical ministries.

\section{Understanding public theology}

The term public theology is labelled as a 'newcomer to the field of religious studies and spirituality' (Van Aarde 2008:1213) and is regarded 'a recent addition to our lexicon' (Day \& Kim 2017:2). Koppel (2015:151) alludes that public theology 'is not a clearly demarcated field'. However, the use of the term is well received and is gaining considerable prevalence in academia with some stating that it goes beyond the parochial ministries of the church and monopoly in doing theology (Cady 1987:193; Day \& Kim 2017:2; McLemore 2018:312). Day and $\operatorname{Kim}(2017: 2)$ further express the same idea as they refer to Cady who proposes that 'the growth of public theology is corrective of individualistic theology which is inaccessible and belonging to the church only' (cf. Cady 1987:193-212). This should not be understood in a manner that dislodges the church as completely having failed to influence communities. The fact that the church exists, is evidence of impact and influence, but it needs to be more explicit and intentional in handling issues of society. Regarding the subject of GBV, the church has been blamed for its silence, theorising and complicit nature regarding GBV as one of the social ills of society (Chisale 2020:1).

Defining public theology remains somehow elusive. Part of this elusiveness emanates from 'multiple definitions' the term has received. In addition, the understanding that the term is new in the field of religious studies as mentioned above, could be a reason for the elusive definition. However, this does not mean that a working conception of the term is impossible (McLemore 2018:312).

In a more general and simplistic manner, public theology is defined as the: '... church reflectively engaging with those within and outside its institutions on issues of common interest and for the common good' (Day \& Kim 2017:2; Koppel 2015:151). On the other hand, Juma (2015:3) cites Thiemann (1991) who advances that public theology: ' ... is faith seeking to understand the relation between Christian convictions and the broader social and cultural content within the Christian community'. Williams (2014:159) also concurs that public theology is Christian faith addressing matters of society and that central to public theology is 'public relevance'. Slight differences and similarities can be discerned from these attempts to construct a definition of this important term. What could be gleaned from the above definitions about public theology is as follows:

- it reflects on and living out our Christian faith;

- it goes beyond the implicit (or parochial) nature of church to a more explicit outlook;
- it is intentional and contextual; and

- it seeks to publicly address social ills for the common good of society.

The understanding follows that the church, in its communal pastoral care, must be driven by public theology. Koopman (2012:4) states that knowledge about God does not only assist us to know reality better, but it helps us to change our reality so that we continually transform and radiate the love of God to humanity. Therefore, in a context of IPV during COVID-19 national lockdown as one of the social issues affecting society, there is need for Christian faith to intentionally and publicly challenge this sometimes imperceptible and violent phenomenon. The immediate concern is to establish why public theology is crucial for the church to address public ills.

\section{The importance and value of public theology in engaging with public issues}

The importance and value of public theology to address public ills of society is pertinent. Ranging from local to global spaces, people are experiencing oppression, poverty, human migration, xenophobia, human trafficking, racism, GBV, infanticide, climate change, politics, civic life, et cetera (De Gruchy 1991:45-62; McLemore 2018:313; Smit 2007:3-5). These mentioned human distress, it could be summarised as human suffering (McClure 2012:270). Given the vastness of human distress, it raises the following questions: How are communities of faith dealing with these realities of life in their theological reflection?; and What reflective transforming theological interventions are being offered by the communities of faith in dealing with public issues and in particular the surge of IPV as a form of GBV amidst the COVID-19 pandemic?

The above questions are realistic and evoke the importance and value of public theology in engaging with public issues. Cady (1987:193) posits the following about theology, '... having lost its power to influence the public debate about our beliefs and actions, theology has increasingly become a privatised form of reflection'. In this private state, the community of faith fails to address human suffering. Therefore, public theology is important and valuable, because human suffering exists. In addition, the advent of public theology allows the community of faith to reclaim its power in public debate so that it can address issues affecting societies through public reflection. 'Reclaiming its power' does not mean that the goal of public theology is to fight a battle, but rather to 'cultivate a sense of common life' (Bezuidenhout \& Naude 2002:11) that allows people to construct transforming solutions to their public issues. The construction of solutions to public issues is achievable through public theology. This allows communities of faith and other social structures outside the church to be able to find each other and work towards transformative interaction to curb public ills. 
In an article, 'A model for public theology', Cady (1987:204) refers to Royce's 1968 publication in which the following about public theology is stated: '... address the central problems of the age rather than perennial, abstract theological issues and reconstruct the tradition in light of contemporary insight'. This means if public theology is going to be important in dealing with public issues, its jargon or language also must not be confusing to those inside and outside ministerial contexts (Bezuidenhout \& Naude 2002:10). Important to public theology is that it aims at communicating the Christian faith to the public, which lead to the framing of pastoral care ministries (Koppel 2015:151).

The importance and value are further realised in that public theology corrects the community of faith from degenerating into private confessions of faith. (Cady 1987:193). This means public theology influences or persuades others to reflect on and embrace transformative ideas on public issues (Cady 1987:194). In addition, public theology affords the church the opportunity to apply its theology to issues of public concern. In doing so, the church should not be swamped by external ideas as it seeks to expand its theology publicly. Instead, the church should 'develop a public theology that remains based in the particularities of the Christian faith which genuinely address issues of public significance' (Bezuidenhout \& Naude 2002:11). Williams (2014:160) poses a question that, I think, reinforces the importance of public theology to public issues. He (Williams 2014:160) says that public theology asks the question 'How is God interfacing with human condition of the moment?' and he adds that 'theology unable to meet this challenge maybe useless in the pursuit of affecting human transformation'. Thus, the salt and light (Mt 5:13-14) effects of the communities of faith must be public and relevant in a manner that transforms the public ills in society.

A further elaboration on public theology at this stage is pertinent. Day and Kim (2017), in their introduction to $A$ companion to public theology, describe the following five important distinctive marks of public theology. This article owes the following five points to Day and Kim (2017:10-16) with some minor alterations:

- The first and key essential mark of public theology is the recognition that theology, to be relevant, is inherently incarnational.

- Public theology must have a sphere of operation and be able to engage public institutions? such as the church, academy and society.

- Public theology must be interdisciplinary by drawing from fields like history, theology and anthropology to understand human experience better.

- Public theology should have the character of being dialogical. In this manner, public theology would speak with (identifying) society instead of speaking to (isolated from) society.

- Public theology should have a global outlook by constantly engaging with issues like religion, politics, technologies, economies, et cetera. This is important, because local contexts do not exist in isolation, but are shaped by what is happening in the global world.
Although public theology is claimed to be a new concept among pastoral and practical theologians, as stated already, the fundamental key aspect about public theology is that it arises out of a need, and the need is to be public. Coupled with the need to be public is the goal to transform the communities of pastoral and practical theologians (Leslie 2008:80-81). To respond to this, Juma (2015:2) refers to Ramsay who advances that, '... redefinition of pastoral theology as public theology also means new delineation of pastoral care's central functions'. To this, Juma responds by saying that the impression one gets from Ramsay seems to be that public theology replaces practical theology. The research coincides with Juma who notes that public theology is not a replacement of practical theology. Instead, 'practical theology finds expression not replacement in public theology' (Juma 2015:2). Public theology may serve as a means or channel through which the other disciplines of theology may find each other with the aim of promoting the concept of individuals expressing their spiritual values and beliefs (Juma 2015:1; Vanhoozer \& Strachan 2015)

According to Koppel (2015:151), 'public theology is not a clearly demarcated field, but generally represents an intention to engage people, develop resources, and strategise on collective level'. The implication gleaned from Koppel is that the intrinsic aim of public theology is to move pastoral and practical theology from an inhibited mode to a more visible and life changing mode. This means public theology is concerned with inhumane aspects of human life and all oppressing social experiences (Day \& Kim 2017:11). In the same vein, at the centre of public theology:

... pastoral care practitioners and theologians are strongly urged to take seriously and engage mindfully with issues that concern groups of people and whole populations, rather than individual persons in isolation. (Hendriks 2007; Koppel 2015:151; Masango 2010)

Regardless of the field in which public theology is utilised, its underpinning goal remains principally as concern for matters affecting people in the public domain (Juma 2015:1; Koppel 2015:151; Leslie 2008:81). Public theology assists the pastoral care theologian to understand the relation between 'Christian convictions and the broader social and cultural context within which the Christian community lives' (Thiemann 1991:30). This means pastoral care and practical theologians' faith must interact within the context to bring positive change. Hence, context determines how one should practise public theology (Garner 2015:22-25; Juma 2015:12; Williams 2014:159). If public theology is not imbedded in the context of the phenomena, it becomes irrelevant and only scratching the surface without addressing the complex nature of societal issues. This entails that IPV in Zimbabwe has two contexts: first, the Zimbabwean culture and gender norms as a context that needs critical attention; and second, the COVID-19 is another context that should determine the framing of public pastoral care ministries without contradicting the WHO and country health guidelines. The exercise of public pastoral care has adapted to the new context. 
To better interact with public issues, the word public needs to be properly understood. Day and Kim (2017:11-12) and Garner (2015:26) suggest three public intitutions to which theology must engage: 'the church, academy and society'. Public theology is not confined to the church and clergy. They cannot have a monopoly on practical theology, but the wider community has a role to play (Ganzevoort \& Roeland 2014:95; Magezi 2017:2; Vanhoozer \& Strachan 2015). There is a debate on the identification of 'public' which public theology should address, and this is not the focus in this article. For the purpose of this research, the identified 'public institutions' help to clarify the word public. Day and Kim (2017:11) concur that 'as long as public is perceived as the public - amorphous and monolithic - any attempt at theological engagement will be abstract and irrelevant'. They further state that the premise of discussion in public theology must not be confined to academic theologians, for this does not serve the social ills of the context(s).

Public theology is used as a larger theoretical lens to establish what the church ought to do with GBV within the church. The church should focus on matters that affect the community (Koppel 2015:151) instead of remaining in an inhibited mode. This means:

\begin{abstract}
... the church is a set-apart public whose life and witness serves the interests of the broader public (i.e., 'every nation and tribe' [Rv 14:6] as well as every social caste and class). Public theology has to do with shaping the people of God to be a hermeneutic of God's love. (Vanhoozer \& Strachan 2015:21)
\end{abstract}

With this in mind, Garner (2015) notes that public theology:
... seeks to offer distinctive and constructive insights from the treasury of faith to help in the building of a decent society, the restraint of evil, the curbing of violence, nation-building ... It strives to offer something that is distinctive, that is gospel, rather than simply adding the voice of theology to what everyone is saying already. (p. 25)

Public theology as an expressive dimension of practical theology, aims at meeting the current human condition with the goal of bringing transformation. This means the nexus between practical theology and public theology is important. Given the above discussion, how could the church be publicly responding to IPV in the context of COVID-19?

\section{Responsive public pastoral care roles for church on gender-based violence during the COVID-19 pandemic}

Studies have proven that churches are well placed in communities to address public issues affecting humanity. Underpinning the activities of the church should be the notion that it is part of the broader community and has a public role to play. The following broader church propositions are responsive public pastoral care roles to mitigate IPV during the COVID-19 pandemic. In its responsive role the church also seeks to answer the following question: 'How does the church become church for others?' (Lawrence 2013:114).

First, government, non-governmental organisations (NGOs) and civil society organisations (CSOs) can be overwhelmed by the need for assistance from victims of IPV. As a microcosm of society, the church should collaborate with the relevant government ministries for gender, NGOs and CSOs, and work together to fight IPV during the COVID-19 pandemic. Given that churches are spread across the country and work closely with communities, they are better positioned to propagate efforts by government and other organisations in reducing the surge of IPV across the nation.

Second, the church could further collaborate with local chiefs and headmen in rural areas to reduce IPV during the COVID-19 pandemic. Pastors and chiefs should identify IPV cases in their communities and offer the necessary psychosocial support to victims. If the case is beyond their assistance, they can both engage the necessary structures for further handling of the case(s). This means that pastors and chiefs need to be empowered with the necessary referencing systems and contact details so that they can communicate with the relevant people. Such measures could also be used to hold the perpetrator accountable for his actions.

Third, Christians form much of the population in Zimbabwean communities (ZIMSTAT 2012:29) and are not exempt from IPV. Not being able to meet with pastors for counselling and sharing what they are going through, could subject some of them to distress and IPV. Pastors need to resort to counselling victims online and extend such services to other people in the community who are victims of IPV. This means that the church members should be able to identify IPV cases and with the consent of the victim refer such cases for pastoral assistance. This could help to compensate for the unplugged support systems caused by COVID-19. Through this approach to public pastoral care, the church becomes a voice to voiceless people in the community.

Fourth, in the event of extreme distress through IPV, the church facilities should be able to provide shelter and other necessary services. While this happens, churches should be cognisant of the COVID-19 health guidelines to avoid the spreading of the pandemic. The church facility should only act as a holding place, place, while more professional assistance is sought for the victim in line with the WHO and government regulations for COVID-19.

Fifth, the church and its membership should engage in GBV awareness campaigns through various social media platforms in their communities. Such platforms should also educate what individuals and the community should do in the event of IPV. This helps community members to be each other's keepers. In this manner, abusive partners and potential abusers could realise that they will be held accountable for their actions. The reason IPV is increasing is that most abusers may not be held accountable for their actions. 
Sixth, both men and women in the church and broader community should work together towards gender justice during and after the pandemic. Some women are abused, because the partner is failing to provide basic necessities for survival during the national lockdown. Men and women in the church should humanely facilitate or provide the victim's needs. This means that church leaders should connect and network with relevant organisations for the provisions of such needs during the COVID-19 pandemic. This will assist some women with abusive husbands to be less dependent on men during this pandemic.

\section{Conclusion}

GBV already existed before COVID-19 in Zimbabwe. Intimate partner violence is a key form of GBV, and the recent national lockdown saw a sharp increase in IPV. The meaning and role of the church in this situation should be evident through its public pastoral care roles. While the COVID-19 pandemic is unparalleled, the church should be alert to public issues around itself and frame transformative intervention measures to uphold the dignity of women. Such public pastoral care roles by the church should be underpinned by a multisectoral approach while cognisant of the COVID-19 health guidelines. In any situation that may threaten the dignity of humanity, the church must be church for itself and the broader community.

\section{Acknowledgements Competing interests}

The authors have declared that no competing interest exist.

\section{Authors' contributions}

All authors contributed equally to this work.

\section{Ethical consideration}

This article followed all ethical standards for carrying out research without direct contact with human or animal subjects.

\section{Funding information}

This research received no specific grant from any funding agency in the public, commercial or not-for-profit sectors.

\section{Data availability statement}

Data sharing is not applicable to this article as no new data were created or analysed in this study.

\section{Disclaimer}

The views and opinions expressed in this article are those of the authors and do not necessarily reflect the official policy or position of any affiliated agency of the authors.

\section{References}

Andria, S. \& Saayman, W., 2003, 'Missiology and ecclesiology: A perspective from Africa', Missionalia 31(3), 503-517. https://doi.org/10.1177/009182960303100432

Ayodapo, O.G., 2013, 'Socio-cultural factors influencing gender-based violence on agricultural livelihood activities of rural households in Ogun State, Nigeria', International Journal of Biodiversity and Conservation 5(1), 1-14.

Bezuidenhout, R. \& Naude, P., 2002, 'Some thoughts on public theology and its relevance for the South African context', Scriptura 79, 3-13.

Brodd, S.E., 2006, 'Themes in operative ecclesiology', International Journal for the Study of the Christian Church 6(2),124-125. https://doi.org/10.1080/14742250600694025

Cady, L.E., 1987, 'A model for a public theology', Harvard Theological Review 80(2), 193-212.

Chisale, S.S., 2020, "Deliver us from patriarchy": A gendered perspective of the Evangelical Lutheran Church in Southern Africa and implications for pastoral care', Verbum et Ecclesia 41(1), a2003. https://doi.org/10.4102/ve.v41i1.2003

Clowney, E.P., 1998, The church: Contours of Christian theology, InterVarsity Press, Downers Grove, IL.

Counts, D., Brown, J.T. \& Campbell, J.,1992, Sanctions and sanctuary: Cultural analysis of the beating of wives, Westview Press, Boulder, CO.

Day, K. \& Kim, S., 2017, 'Introduction', in K. Day \& S. Kim (eds.), A companion to public theology, pp. 1-24, Brill, Boston, MA.

De Gruchy, J.W., 1991, Liberating reformed theology: A South African contribution to an Ecumenical debate, Eerdmans, Grand Rapids, MI.

Dingemans, G.D.J., 1996, 'Practical theology in the academy: A contemporary overview', The Journal of Religion 76(1), 82-96. https://doi.org/10.1086/489737

EIGE, 2017, Terminology and indicator for data collection: Rape, femicide and intimate partner violence, viewed 26 June 2020, from https://eige.europa.eu/publications/ terminology-and-indicators-data-collection-rape-femicide-and-intimate-partnerviolence-report

Ganzevoort, R.R. \& Roeland, J.H., 2014, 'Lived religion: The praxis of practical theology', International Journal of Practical Theology 18(1), 91-101. https://doi. org/10.1515/ijpt-2014-0007

Garner, S., 2015, 'Contextual and public theology: Passing fads or theological imperatives?', The New Zealand Journal of Christian Thought and Practice 22(1), 20-28.

Heise, L. \& Ellsberg, M., 1999, 'Population reports, ending violence against women', Centre for Health and Gender Equity XXVII(4), 1-44.

Heise, L., Ellsberg, M. \& Gottmoeller, M., 2002, 'A global overview of gender based violence', International Journal of Gynecology and Obstetrics 78(1), S5-S14.

Hendriks, J.H., 2007, 'Missional theology and social development', HTS 63(3), 999-1016. https://doi.org/10.4102/hts.v63i3.244

Jewkes, R., 2002, 'Intimate partner violence: Causes and prevention', The Lancet 359, 1423-1429. https://doi.org/10.1016/S0140-6736(02)08357-5

Julia, C.K., Watts, C.H., Hargreaves, J.R., et al., 2011, 'Understanding the impact of a microfinance-based intervention on women's empowerment and the reduction of intimate partner violence in South Africa', American Journal of Public Health 97(10), 1794-1802. https://doi.org/10.2105/AJPH.2006.095521

Juma, F, 2015, 'Public theology in the face of pain and suffering: A proletarian perspective', Consensus, 36(2), 1-14.

Koopman, N., 2012, 'Public theology in pluralistic societies? Lessons from the theology of Etienne de Villiers', Verbum et Ecclesia 33(2), Art. \#773, 6 pages. https://doi. org/10.4102/ve.v33i2.773

Koppel, S.M., 2015, 'Practicing public pastoral theologies in contexts of difference', Journal of Pastoral Theology 25(3), 151-152. https://doi.org/101080/10649867.2 015.1123923

Kruttschnitt, C., Yule, C., Alper, M. \& Klassen A., 2018, 'Situational variations in, and women's accounts of, avoided acts of serious intimate partner violence', Violence against Women 24(4), 477-501. https://doi.org/10.1177/1077801217708057

Landenburger, R.N., 1998, 'Process of experiencing and recovering from abusive relationships', in A. Kathleen \& T Kendall (eds.), Handbook of women, stress and trauma, pp. 131-135, Brunner-Routledge, New York, NY.

Lawrence, J.D., 2013, 'Death together: Dietrich Bonhoeffer on becoming the church for others', in K.L. Johnson \& T. Larsen (eds.), Bonhoeffer, Christ and culture, pp. 113-130, IVP Academic, Downers Grove, IL.

Leslie, K.J., 2008, 'Pastoral care in a new public: Lessons learned in the public square' Journal of Pastoral Theology 18(2), 80-99. https://doi.org/10.1179/ jpt.2008.18.6/2.005

Louw, D.J., 1998, A pastoral hermeneutics of care and encounter a theological design for a basic theory, anthropology, method and therapy, Lux Verbi, Wellington.

Magezi, V., 2017, 'Public pastoral care as nexus and opportunity for transformed practical theology within decolonisation discourse in South Africa higher education', In die Skriflig 52(1), a2327. https://doi.org/10.4102/ids.v52i1.2327

Magezi, V. \& Magezi, C., 2018, 'Migration crisis and Christian response: From Daniel De Groody's image of God Theological Prism in migration theology to a migration practical theology ministerial approach and operative ecclesiology', HTS Teologiese Studies/Theological Studies 74(1), 4876. https://doi.org/10.4102/hts. v74i1.4876

Masango, M.J., 2010, 'Is prophetic witness the appropriate mode of public discourse on the global economy?', HTS Teologiese Studies/Theological Studies 66(1), a772. https://doi.org/10.4102/hts.v66i1.772 
McClure, B., 2012, 'Pastoral care', in J.M. McLemore (ed.), The Wiley-Blackwell companion to practical theology, 1st edn., pp. 269-270, Blackwell Publishing Ltd. Hoboken, NJ.

McLemore, B.J.M., 2018, The living human web: A twenty-five-year retrospective, Vanderbilt University, Nashville, TN.

Mutepfa, M.M., 2009, Spousal abuse in Zimbabwe: Nature and extend across socioeconomic class, gender and religiosity, viewed 24 June 2020, from https://dialnet. unirioja.es/descarga/articulo/5216158.pdf.

Mutongwiza, L., 2020, Gender based violence, a pandemic within a pandemic, viewed 23 June 2020, from https://blogs.lse.ac.uk/africaatlse/2020/04/23/gender23 June 2020, from https://blogs.Ise.ac.uk/africaatlse/

Nhlapo, Z., 2017, 5 shocking facts about intimate partner violence in South Africa, viewed 25 June 2020, from https://www.huffingtonpost.co.uk/2017/05/12/5 shocking-facts-about-intimate-partner-violence-in-south-africa_a_22083035/?gu ccounter=1\&guce_referrer=aHROcHM6Ly93d3cuZ29vZ2xIIL-2NNvS8\&guce ceferer_sig=AQAAANNhqnPkShYeGhVolzlywpmNmAeR3aJrj1YCNuCWRVW12Gwfg
Atzh6-BvnYfcpaE6rr-lu5KXHWbJh3T4tZhx17NWdWfWrb2vSqmicUbZIpCqMcXOK Atzh6-BvnYfcpaE6rr-lu5KXHWbJh3T4tZhx17NWdWfWrb2vSqmicUbZlpCqMcXO
Ud5OnpkHwBpQORGRqyQkkrY8o_ZacOMO1RdN1aOn5I81yQqPCpXmtWtS22a.

Office for the Coordination of Humanitarian Affairs (OCHA), 2020, Zimbabwe cluster status: Protection (gender-based violence), last updated: 11 June 2020, viewed 19 June 2020, from https://reports.unocha.org/en/country/zimbabwe/card/2XxB9GOV93/.

Osmer, R., 2008, Practical theology: An introduction, WB Eerdmans, Grand Rapids, MI.

Population International Services (PSI), 2015, Evidence series: Gender based violence, viewed 24 June 2020, from https://www.psi.org/wp-content/uploads/2020/02/ GBV_EvidenceSeries_Jun2015.pdf.

Rio, I.D. \& Valle, E.S.G., 2017, 'The consequences of intimate partner violence on health: A further disamen

Shamu, S., Abrahams, N., Zarowsky, C., Shefer, T. \& Temmerman, M., 2013, Intimate partner violence during pregnancy in Zimbabwe: A cross sectional study of prevalence, predictors and associations with HIV, viewed 26 June 2020, from https//aids.usaid.gov/resources/prevention-update/editions/april2013/ intimatepartnerviolence.

Smit, D.J., 2007, Essays in public theology, SUN Press, Stellenbosch.

Substance Abuse and Mental Health Service Administration (SAMHSA), 2020, Intimate partner violence and child abuse considerations during COVID-19, viewed 24 June
2020, from https://www.samhsa.gov/sites/default/files/social-distancing-domesticviolence.pdf

Thiemann, R.F., 1991, Constructing a public theology - The church in pluralistic culture, Westminster/John Knox Press, Louisville, KY.

United Nations Development Programme (UNDP), 2020, Gender-based violence and COVID-19, viewed 24 June 2020, from https://www.undp.org/content/undp/en/ home/librarypage/womens-empowerment/gender-based-violence-andcovid-19.html.

United Nations Fund for Population Activities (UNFPA), 2020, Eastern and Southern Africa Region COVID-19 situation report no. 1, viewed 23 June 2020, from https:// reliefweb.int/report/angola/eastern-and-southern-africa-region-covid-19situation-report-no-1.
United Nations Women (UNW), 2016, Facts and figures: Ending violence against women, viewed 20 June 2020, from http://www.unwomen.org/en/what-we-do/ ending-violence-against-women/facts-and-figures\#sthash.pxEul6uo.dpuf.

United Nations Women (UNW), 2018, Annual report 2017-2018, viewed 23 June 2020, from https://www.unwomen.org/en/digital-library/publications/2018/6/ annual-report-2017-2018

United Nations Zimbabwe, 2020, Urgent action on looming violence against women during COVID-19 pandemic, viewed 23 June 2020, from http://zw.one.un.org/ newsroom/news/urgent-action-looming-violence-against-women-during-covid19-pandemic.

Van Aarde, A., 2008, "What is "theology" in public theology and what is "public" about public theology', HTS Teologiese Studies/Theology Studies 63(3), 1213-1234. https://doi.org/10.4102/hts.v64i3.81

Vanhoozer, K.J. \& Strachan, O., 2015, The pastor as a theologian: Reclaiming a lost vision, Baker Academic, MI.

Watts, C. \& Zimmerman, C., 2002, 'Violence against women: Global scope and magnitude', The Lancet 359(93113), 1232-1237.

Weed, K.W., n.d, Facing reality, viewed 15 June 2020 from http://store.fortresspress. com/media/downloads/0800697553Chapter1.pdf.

Williams, B., 2014, 'Prophetic public theology', Review and Expositor 11(2), 159-170, https://doi.org/10.1177/00346373145250008

World Health Organisation (WHO), 2010, Preventing intimate partner and sexual violence against women: Taking action and generating evidence, viewed 19 June 2020, from https://www.who.int/violence_injury_prevention/publications/ violence/9789241564007_eng.pdf?ua=1.

World Health Organisation (WHO), 2012, Understanding and addressing violence against women: Intimate partner violence, viewed 20 June 2020, from http:// www.who.int/iris/handle/10665/77432.

World Health Organization (WHO), 2013, Responding to intimate partner violence and sexual violence against women: WHO clinical and policy guidelines, Geneva, viewed 17 June 2020, from https://www.who.int/reproductivehealth/ publications/violence/9789241548595/en/.

Zimbabwe Demographic Health Survey (ZDHS), 2010-2011, Key findings, viewed 22 June 2020, from https://dhsprogram.com/pubs/pdf/FR254/FR254.pdf.

Zimbabwe Demographic Health Survey (ZDHS), 2015, Key findings, viewed 19 June 2020, from https://www.dhsprogram.com/pubs/pdf/SR234/SR234.pdf

ZIMFACT, 2020, Domestic violence during corona virus lockdown, viewed 21 June 2020, from https://zimfact.org/factsheet-domestic-violence-during-coronaviruslockdown/.

ZIMSTAT, 2012, Demographic and Health Survey 2010-2011, viewed 23 June 2020 from https://www.google.co.za./search?q=demographic+health+survey+zimbab we+2010-2011\&oq. 